\title{
Effects of light intensity and temperature on Cylindrospermopsis raciborskii (Cyanobacteria) with straight and coiled trichomes: growth rate and morphology
}

\author{
Bittencourt-Oliveira, MC. ${ }^{a, b *}$, Buch, B. ${ }^{a, b}$, Hereman, TC..$^{a, b}$, \\ Arruda-Neto, JDT. ${ }^{c, d}$, Moura, AN. ${ }^{e}$ and Zocchi, SS. ${ }^{f}$ \\ aDepartamento Ciências Biológicas, Escola Superior de Agricultura "Luiz de Queiroz" - ESALQ, \\ Universidade de São Paulo - USP, Av. Pádua Dias, 11, CEP 13418-900, Piracicaba, SP, Brazil

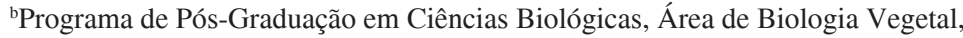 \\ Universidade Estadual Paulista - UNESP, Av. 24-A, 1515, CEP 13506-900, Rio Claro, SP, Brazil \\ 'Laboratório do Acelerador Linear, Instituto de Física - IF, Universidade de São Paulo - USP, São Paulo, SP, Brazil \\ ${ }^{\mathrm{d}}$ Italy-Brazilian University Center, São Paulo, SP, Brazil \\ 'Departamento de Biologia, Área de Botânica, Universidade Federal Rural de Pernambuco - UFRPE, \\ Rua D. Manoel de Medeiros, s/n, Dois Irmãos, CEP 52171-030, Recife, PE, Brazil \\ fDepartamento de Ciências Exatas, Escola Superior de Agricultura "Luiz de Queiroz" - ESALQ, \\ Universidade de São Paulo - USP, Av. Pádua Dias, 11, CEP 13418-900, Piracicaba, SP, Brazil \\ *e-mail: mbitt@usp.br \\ Received January 24, 2011 - Accepted June 28, 2011 - Distributed May 31, 2012 \\ (With 6 figures)
}

\begin{abstract}
Cylindrospermopsis raciborskii (Woloszynska) Seenayya et Subba Raju (Ordem Nostocales) is one of the most troublesome bloom-forming species in Brazil. Understanding the population dynamics of the different morphotypes of $C$. raciborskii (straight and coiled) could assist in the prediction of favourable conditions for the proliferation of this potentially toxin-producing species. The aim of the present study was to assess the effects of two different light intensities and temperatures on the growth rate and morphology of the trichomes of the straight and coiled morphotypes. For such, two non-toxin producing strains of $C$. raciborskii were used - one with a coiled trichome (ITEP31) and another with a straight trichome (ITEP28). The strains were cultured in BG-11 medium in a climatic chamber under controlled conditions. Two light intensities $\left(30\right.$ and $\left.90 \mu \mathrm{mol} . \mathrm{m}^{-2} \cdot \mathrm{s}^{-1}\right)$ were combined at temperatures of 21 and $31{ }^{\circ} \mathrm{C}$ and the growth rate and morphological changes were analysed. The morphotypes responded differently to the different temperatures and light intensities. Both strains exhibited faster growth velocities when submitted to higher light intensity and temperature. The lower temperature and higher luminosity hampered the development of both strains. Variations in cellular morphology and an absence of akinetes in both strains were related to the lower temperature $\left(21^{\circ} \mathrm{C}\right)$. The coiled morphotype demonstrated considerable phenotype plasticity, changing the morphology of trichome throughout its growth curve. Although molecular analysis does not sustain the separation of the morphotypes as distinct species, their different eco-physiological responses should be considered further knowledge of extreme importance for the population control of these potentially toxic organisms.
\end{abstract}

Keywords: cyanobacteria, morphotype, growth curve, culture.

\section{Efeitos da intensidade luminosa e temperatura em Cylindrospermopsis raciborskii (Cyanobacteria) com tricomas retos e espiralados: taxa de crescimento e morfologia}

\begin{abstract}
Resumo
Cylindrospermopsis raciborskii (Woloszynska) Seenayya et Subba Raju (Ordem Nostocales) é uma das espécies formadoras de florações mais prejudiciais no Brasil. Entender a dinâmica populacional dos diferentes morfotipos de C. raciborskii (reto e espiralado) pode auxiliar a previsão de condições favoráveis à proliferação e ao estabelecimento dessa espécie potencialmente produtora de saxitoxinas e cilindrospermopsina. O objetivo deste estudo foi avaliar os efeitos de duas diferentes intensidades luminosas e temperaturas na velocidade de crescimento e na morfologia dos tricomas de morfotipos reto e espiralado. Para tanto, foram utilizadas duas linhagens de C. raciborskii, não produtoras de toxinas, sendo uma com tricoma espiralado (ITEP31) e outra com tricoma reto (ITEP28), cultivadas em câmaras climáticas sob condições controladas em meio BG-11. Duas intensidades luminosas, 30 e $90 \mu \mathrm{mol} . \mathrm{m}^{-2} \cdot \mathrm{s}^{-1}$, foram
\end{abstract}


combinadas com temperaturas de 21 e $31^{\circ} \mathrm{C}$ e avaliadas as velocidades de crescimento e modificações morfológicas. Os morfotipos responderam de maneiras diferentes às temperaturas e intensidades luminosas. As linhagens investigadas, independentemente do morfotipo, apresentaram maiores velocidades de crescimento em intensidade luminosa e temperatura altas. A condição de temperatura baixa e intensidade luminosa alta prejudicaram o desenvolvimento de ambas as linhagens. Variações na morfometria celular, bem como a ausência de acinetos para ambas as linhagens, estiveram relacionadas às condições de temperatura baixa $\left(21^{\circ} \mathrm{C}\right)$. O morfotipo espiralado apresentou grande plasticidade fenotípica, alterando a morfologia do tricoma ao longo de sua curva de crescimento. Apesar de a análise com ferramentas moleculares não sustentar a separação dos morfotipos em espécies distintas, devem-se considerar as diferentes respostas ecofisiológicas entre os mesmos como conhecimento de extrema importância no controle populacional desses organismos potencialmente tóxicos.

Palavras-chave: cyanobacteria, morfotipo, curva de crescimento, cultivo.

\section{Introduction}

Blooms of C. raciborskii (Wolosynska) Seenayya et Subba Raju, whether or not accompanied by the production of cyanotoxins, have been common in recent decades and are more frequent in lakes in temperate regions than in tropical bodies of water (Padisák, 1997). However, C. raciborskii develops in a variety of environments from oligotrophic reservoirs to shallow, hypereutrophic lakes and even rivers. Such sites offer wide diversity of habitats in terms of geo-morphology and chemical composition of the water, indicating a high degree of eco-physiological adaptation on the part of this species (Fabbro and Duivenvoorden, 1996; Padisák, 1997; Bouvy et al., 1999).

Based on traditional morphological criteria, the trichome shape is an important characteristic in the distinction of species of Cylindrospermopsis. This taxon exhibits extensive phenotype plasticity, with straight, sigmoid and coiled trichomes occurring in the same body of water (Bouvy et al., 1999; Komarková et al., 1999). Molecular studies have indicated that the different morphotypes of C. raciborskii should be considered as pertaining to the same species due to the high degree of genetic similarity (Saker et al., 1999; Wilson et al., 2000; Dyble et al., 2002; Chonudonkul et al., 2004).

In a shallow, eutrophic tropical reservoir in northeastern Brazil (Mundaú reservoir), Bittencourt-Oliveira et al. (2011) found that the coiled morphotype tends to seek strata with low luminosity associated with warm temperatures. In the body of water in question, thermal destratification favours an increase in the populations of both morphotypes by providing more favourable conditions for growth. On the other hand, in the Solomon Dam in Australia, Saker et al. (1999) found no preference of the straight and coiled morphotypes with regard to variations in temperature, which underscores the wide eco-physiological diversity of $C$. raciborskii populations.

The aim of the present study was to assess the effects of two different light intensities and temperatures on the growth rate and morphology of the trichomes of the straight and coiled morphotypes of $C$. raciborskii.

\section{Material and Methods}

\subsection{Strains and culture conditions}

Two non-toxin-producing clonal strains of $C$. raciborskii were used - one with a coiled trichome (ITEP31) and the other with a straight trichome (ITEP28) (Figure 1). The strains were isolated from an ornamental lake ( $8^{\circ} 03$ ' 32" S and $34^{\circ} 5653^{\prime \prime} \mathrm{W}$ ) belonging to the Instituto de Tecnologia de Pernambuco (ITEP) in the city of Recife (northeastern Brazil) in September 2002 and kept in climatic chambers under controlled light $\left(30 \mu \mathrm{mol} \cdot \mathrm{m}^{-2} \cdot \mathrm{s}^{-1}\right)$, photoperiod (14:10 hours light-dark) and temperature $\left(21 \pm 0.5^{\circ} \mathrm{C}\right)$ in a BG-11 culture medium (Rippka et al., 1979), modified based on Bittencourt-Oliveira (2000), with pH 7.8.

The cultures of ITEP28 E ITEP31 strains from which the inoculums were to be withdrawn were previously acclimatised for 30 days under the same conditions used for the obtainment of the growth curves. Four experiments were carried out for the two strains with light intensities of 30 and $90 \mu \mathrm{mol} \cdot \mathrm{m}^{-2} \cdot \mathrm{s}^{-1}$ combined with temperatures of 21 and $31^{\circ} \mathrm{C}$ in climatic chambers using $3 \mathrm{~L}$ erlenmeyer flasks containing $2.2 \mathrm{~L}$ of medium with triplicates for each strain. All growth curves were initiated with inoculums of $10^{4}$ trichomes. $\mathrm{mL}^{-1}$

The culture medium necessary for each combined light intensity and temperature experiment was prepared at single time in order to ensure uniformity. Light intensity was measured with the aid of a LI-COR light meter equipped with a spherical underwater sensor (mod. LI-250) immersed in the water at the exact position at which the flasks were to be located. The higher light intensity and temperature values $\left(90 \mu \mathrm{mol} \cdot \mathrm{m}^{-2} \cdot \mathrm{s}^{-1} / 31^{\circ} \mathrm{C}\right)$ were established following a pilot experiment using $130 \mu \mathrm{mol} \cdot \mathrm{m}^{-2} \cdot \mathrm{s}^{-1} / 31^{\circ} \mathrm{C}$, in which the strains did not survive.

\subsection{Morphometric analysis}

The morphological analysis was performed based on the measurement of vegetative cells $(n=400)$, heterocysts ( $n=100$ to 200$)$ and akinetes ( $n=60$ to 150$)$, determined using a binocular microscope (Nikon E200, Melville, NY, USA) with an ocular measurement coupled to the system. Ten trichomes were randomly selected using the charriot 

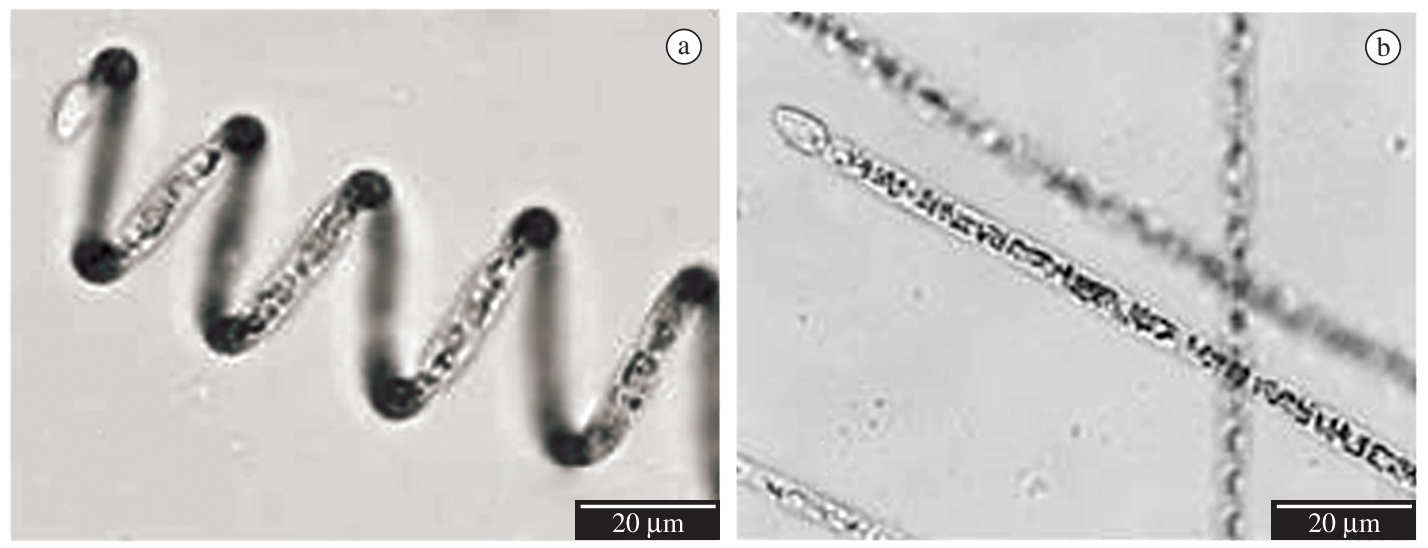

Figure 1. Coiled (ITEP31) and straight (ITEP28) morphotypes used in present study.

microscopic rule and length and width measurements of randomly selected cells from each trichome were determined. This procedure was repeated for all samples collected daily during different phases of the study until reaching the $n$ values above established.

Photodocumentation was performed with living organisms using the ImageLab program (Softium, São Paulo, Brazil) coupled to the optical microscope, which was equipped with a digital camera (Samsung SCC833, Tokyo, Japan).

\subsection{Molecular analysis}

Total genomic DNA was prepared using the Genome kit (BIO 101, Vista, CA, USA), following the manufacturer's recommendations. The conditions for the amplification reactions were based on Bittencourt-Oliveira et al. (2007). Polymerase chain reactions were performed using extended HIP1 primers: HIP-CA: (5'-GCGATCGCCA-3'), HIP-GC (5'-GCGATCGCGC-3'), HIP-AT (5'-GCGATCGCAT-3') and HIP-TG (5'-GCGATCGCTG-3'). All reactions were accompanied by a control (without DNA). HIP1-amplified fragments obtained from four primers were assembled and converted into binary codes based on the presence or absence of data. The similarity value was calculated using the Jaccard coefficient (Jaccard, 1901) with the aid of the NTSYS program, version 2.1 (NTSYS-PC 2002).

\subsection{Quantitative analysis}

Daily samples were retrieved for the quantification of cell density. The average number of cells for trichome was 20 to 30 respectively for straight and coiled morphotypes. The count of the trichomes was carried out because of the difficulty in viewing the cells due to the presence of aerotopes, thus, a minimum number of 400 trichomes per sample was randomly counted. The counts were performed in a Fuchs-Rosenthal chamber with the aid of an optical microscope (Nikon E200, Melville, NY, USA), with an error of approximately 10 for a $95 \%$ confidence level (Guillard, 1973).

\subsection{Obtainment of growth rate curves}

The number of days of growth curve varied between 120 to 170 days by virtue of strain metabolic time on the different conditions of light and temperature intensity.

The number of trichomes for each sample day (y), as function of time (x) was fitted by the following equation deduced from a logistic growth model with three parameters (Caria, 2000):

$$
\mathrm{y}=\frac{\phi_{1}}{1+\exp \left(\phi_{2}-\mathrm{x} / \phi_{3}\right)}
$$

in which $\phi_{1}$ is the vertical asymptote [the maximal size the population can reach over a period of time $(\mathrm{x} \rightarrow \infty)$ ]; $\phi_{2}$ is the time needed for the population to reach half its maximal size $\left(\phi_{1} / 2\right)$; and $\phi_{3}$ is a scale parameter, which is inversely proportional to the maximal growth rate. For comparison between treatments, the instantaneous growth rate of the population in time $x=\phi_{2}$ was also calculated and given by $\phi_{1} /\left(4 \phi_{3}\right)$, corresponding to maximal rate.

A more complete way to analyse growth is through the behaviour of the velocities for all observation times. Although this measure was not performed directly, the analysis of the data through a logistic equation followed by the calculation of the temporal derivative of this equation allowed obtaining daily velocities $-\mathrm{V}(\mathrm{x})$. Thus, the growth rate curves were obtained by deriving in time (x) the expression (1) from which the following was obtained Equation 2):

$$
\begin{aligned}
& \mathrm{V}(\mathrm{x})=\mathrm{dy} / \mathrm{dx}=\left(\phi_{1} / \phi_{3}\right) \times\left(\exp \left[\left(\phi_{2}-\mathrm{x}\right) / \phi_{3}\right] /\right. \\
& \left\{1+\exp \left[\left(\phi_{2}-\mathrm{x}\right) / \phi_{3}\right]\right\}^{2}
\end{aligned}
$$

Graphs were constructed with the aid of the OriginPro 7.5 program (OriginLab, Massachusetts, USA).

\subsection{Statistical analysis}

Measurement and standard deviation of length and width pattern of vegative cells, heterocytes and akinetes, were calculated using a Microsoft Excel program (Microsoft Office 2007) in four conditions tested and graphs produced 
using the Bioestat 5.0 program (Ayres et al., 2005). Analysis of variance (ANOVA, 5\% level of significance) was used to determine occurrence of difference among conditions; the Tukey test at 5\% used posteriorly. The Statistic 2004 program (StaSoft, Inc., Tulsa, OK, USA) was used for these analyses.

\section{Results}

\subsection{Molecular analysis}

The strains ITEP28 (straight) and ITEP31 (coiled) exhibited $91.2 \%$ similarity, indicating that they belong to the same species.

\subsection{Trichome morphology}

Morphological alterations occurred in both strains under all tested conditions. However, with $30 \mu \mathrm{mol} . \mathrm{m}^{-2} \cdot \mathrm{s}^{-1} / 31{ }^{\circ} \mathrm{C}$, the coiled morphotype became straight and sigmoid, while under the condition of $30 \mu \mathrm{mol} \cdot \mathrm{m}^{-2} \cdot \mathrm{s}^{-1} / 21^{\circ} \mathrm{C}$, part of these trichomes returned to their original coiled shape. Under all tested conditions, thinner trichomes were observed in both strains during the stationary phase.

\subsection{Vegetative cells}

The greatest metric variation in cell width occurred in both morphotypes with conditions of $30 \mu \mathrm{mol} \cdot \mathrm{m}^{-2} \cdot \mathrm{s}^{-1} / 21^{\circ} \mathrm{C}$ and $90 \mu \mathrm{mol} . \mathrm{m}^{-2} \cdot \mathrm{s}^{-1} / 21{ }^{\circ} \mathrm{C}$ (Figure 2), whereas the least variation in width occurred under the condition of $90 \mu \mathrm{mol} . \mathrm{m}^{-2} . \mathrm{s}^{-1} / 31^{\circ} \mathrm{C}$. Statistically significant differences were detected in width and length values for both strains (Figure 2, Table 1).

\subsection{Heterocysts}

Significant differences were detected in heterocyst width for both morphotypes. No significant differences were detected in heterocyst length for straight strain ITEP28 (Table 1). The coiled strain (ITEP31) exhibited greater variation under the condition of $90 \mu \mathrm{mol} \cdot \mathrm{m}^{-2} \cdot \mathrm{s}^{-1} / 21{ }^{\circ} \mathrm{C}$ (Figure 2). Heterocysts occurred with the different conditions tested and remained until the end of the exponential phase, except in the straight strain (ITEP28) under the $90 \mu \mathrm{mol} . \mathrm{m}^{-2} \cdot \mathrm{s}^{-1} / 21^{\circ} \mathrm{C}$. At this same condition, the coiled strain had only heterocysts at the beginning of the exponential phase, around 25 days of growth.

\subsection{Akinetes}

Akinetes were found between the median portion of the trichome and its extremity, closer to the heterocyst, with one to four akinetes per individual. The coiled morphotype (ITEP31) did not produce akinetes with $90 \mu \mathrm{mol} . \mathrm{m}^{-2} \cdot \mathrm{s}^{-1} / 2{ }^{\circ} \mathrm{C}$ and exhibited the greatest and smallest variations on width at $30 \mu \mathrm{mol} . \mathrm{m}^{-2} \cdot \mathrm{s}^{-1} / 21^{\circ} \mathrm{C}$ and 90 umol. $\mathrm{m}^{-2} \cdot \mathrm{s}^{-1} / 31^{\circ} \mathrm{C}$, respectively. The straight morphotype (ITEP28) did not produce akinetes under the conditions of $90 \mu \mathrm{mol} . \mathrm{m}^{-2} \cdot \mathrm{s}^{-1} / 2{ }^{\circ} \mathrm{C}$ or $30 \mu \mathrm{mol} \cdot \mathrm{m}^{-2} \cdot \mathrm{s}^{-1} / 21{ }^{\circ} \mathrm{C}$, and there was small variation in width values (Figure 3 ). No statistically significant differences in akinete length were detected in straight strain (ITEP28) under any of the tested
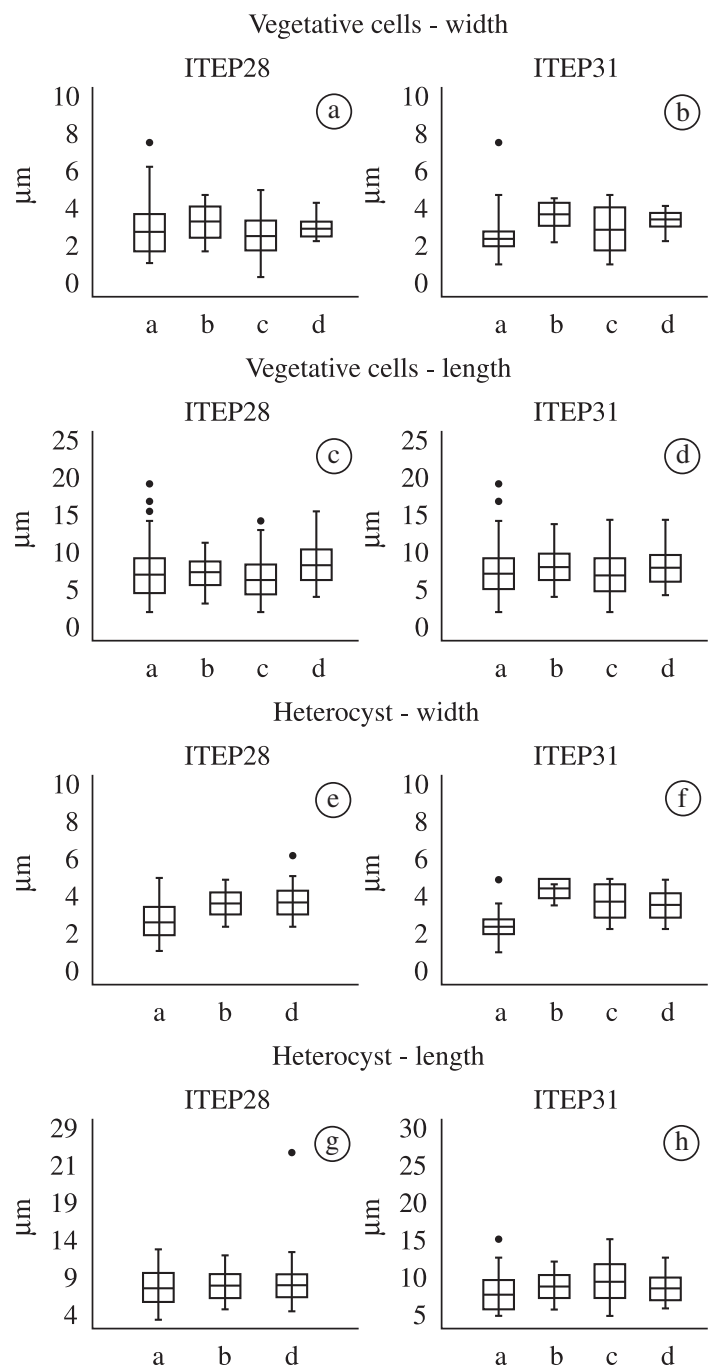

Figure 2. Variations of cellular dimensions, mean and standard deviations obtained under different conditions for strains ITEP28 (straight) and ITEP31 (coiled); a-b) Width of vegetative cells $(n=400)$; c-d) Length of vegetative cells $(n=400)$; e-f) Width of heterocysts $(n=100-200)$; g-h) Length of heterocysts $(\mathrm{n}=100-200)$; Assays: a) $30 \mu \mathrm{mol} \cdot \mathrm{m}^{-2} \cdot \mathrm{s}^{-1}$ and $21^{\circ} \mathrm{C}$; b) $30 \mu \mathrm{mol} \cdot \mathrm{m}^{-2} \cdot \mathrm{s}^{-1}$ and $31^{\circ} \mathrm{C}$; c) $90 \mu \mathrm{mol} \cdot \mathrm{m}^{-2} \cdot \mathrm{s}^{-1}$ and $21^{\circ} \mathrm{C}$; d) $90 \mu \mathrm{mol} \cdot \mathrm{m}^{-2} \cdot \mathrm{s}^{-1}$ and $31^{\circ} \mathrm{C}$.

conditions (Figure 3, Table 1). Significant differences were detected in heterocyst length and width for the coiled strain ITEP31 (Table 1). The akinetes were generally present in both strains until the middle of the exponential phase, and the number of akinetes was higher when a drop in the growth rate was verified.

\subsection{Growth rate curves}

Table 2 displays the estimates of the parameters of the logistic model and growth rates under the different experimental conditions as well as the respective coefficients of determination $\left(\mathrm{R}^{2}\right)$. Figures 4 and 5 display the growth curves and a comparison of maximal growth rates between 
Table 1. Results of variance analyses ANOVA one factor and Tukey test (5\%) for morphological dates. C1: Condition 1 $\left(30 \mu \mathrm{mol} \cdot \mathrm{m}^{-2} \cdot \mathrm{s}^{-1}\right.$ and $\left.31^{\circ} \mathrm{C}\right)$; C2: Condition $2\left(30 \mu \mathrm{mol} \cdot \mathrm{m}^{-2} \cdot \mathrm{s}^{-1}\right.$ and $\left.21{ }^{\circ} \mathrm{C}\right)$; C 3 : Condition $3\left(90 \mu \mathrm{mol} \cdot \mathrm{m}^{-2} \cdot \mathrm{s}^{-1}\right.$ and $\left.31{ }^{\circ} \mathrm{C}\right)$; $\mathrm{C} 4$ : Condition $4\left(90 \mu \mathrm{mol} \cdot \mathrm{m}^{-2} \cdot \mathrm{s}^{-1}\right.$ and $\left.31^{\circ} \mathrm{C}\right)$. Conditions followed by the same letter did not present significant differences.

\begin{tabular}{|c|c|c|c|c|c|c|c|}
\hline & \multicolumn{3}{|c|}{ Strain 28} & \multicolumn{3}{|c|}{ Strain 31} \\
\hline & & $\mathbf{F}$ & $p$ & Conditions & $\mathbf{F}$ & $p$ & Conditions \\
\hline \multirow{8}{*}{$\begin{array}{l}\text { Vegetative } \\
\text { cells }\end{array}$} & \multirow{5}{*}{ Width } & \multirow{4}{*}{52.715} & \multirow{4}{*}{$<0.0001$} & $\mathrm{C} 1^{\mathrm{c}}$ & \multirow{5}{*}{264.298} & \multirow{4}{*}{$<0.0001$} & $\mathrm{C} 1^{\mathrm{d}}$ \\
\hline & & & & $\mathrm{C} 2^{\mathrm{b}}$ & & & $\mathrm{C} 2^{\mathrm{a}}$ \\
\hline & & & & $\mathrm{C} 3^{\mathrm{b}}$ & & & $\mathrm{C} 3^{\mathrm{c}}$ \\
\hline & & & & $\mathrm{C} 4^{\mathrm{a}}$ & & & $\mathrm{C} 4^{\mathrm{a}}(p<0.01)$ \\
\hline & & \multirow{4}{*}{48.025} & \multirow{4}{*}{$<0.0001$} & $\mathrm{C} 1^{\mathrm{b}}$ & & \multirow{4}{*}{$<0.0001$} & $\mathrm{C} 1^{\mathrm{b}}$ \\
\hline & \multirow{3}{*}{ Length } & & & $\mathrm{C} 2^{\mathrm{b}}$ & \multirow{3}{*}{29.726} & & $\mathrm{C} 2^{\mathrm{a}}$ \\
\hline & & & & $\mathrm{C} 3^{\mathrm{c}}$ & & & $\mathrm{C} 3^{\mathrm{b}}$ \\
\hline & & & & $\mathrm{C} 4^{\mathrm{a}}$ & & & $\mathrm{C} 4^{\mathrm{a}}(p<0.05)$ \\
\hline \multirow{7}{*}{ Heterocysts } & \multirow{4}{*}{ Width } & \multirow{3}{*}{94.517} & \multirow{3}{*}{$<0.0001$} & $\mathrm{C} 1^{\mathrm{b}}$ & \multirow{3}{*}{329.316} & \multirow{3}{*}{$<0.0001$} & $\mathrm{C}^{\mathrm{d}}$ \\
\hline & & & & $C 2^{\mathrm{a}}$ & & & $\mathrm{C} 2^{\mathrm{a}}$ \\
\hline & & & & $\mathrm{C} 3^{\mathrm{b}}$ & & & $\begin{array}{c}\mathrm{C}^{\mathrm{b}} \\
\mathrm{C} 4^{\mathrm{d}}(p<0.01)\end{array}$ \\
\hline & & \multirow{4}{*}{2.547} & \multirow{4}{*}{0.077} & & \multirow{4}{*}{34.98} & \multirow{4}{*}{$<0.0001$} & $\mathrm{C} 1^{\mathrm{b}}$ \\
\hline & \multirow{3}{*}{ Length } & & & & & & $\mathrm{C}^{\mathrm{a}}$ \\
\hline & & & & & & & $\mathrm{C}^{\mathrm{b}}$ \\
\hline & & & & & & & $\mathrm{C} 4^{\mathrm{c}}(p<0.01)$ \\
\hline \multirow{6}{*}{ Akinetes } & & & & & & & $\mathrm{C} 1^{\mathrm{b}}$ \\
\hline & Width & 1.098 & 0.296 & & 46.269 & $<0.0001$ & $\mathrm{C} 2^{\mathrm{a}}$ \\
\hline & & & & & & & $\mathrm{C} 3^{\mathrm{b}}(p<0.01)$ \\
\hline & \multirow{3}{*}{ Length } & \multirow{3}{*}{0.001} & \multirow{3}{*}{0.978} & & \multirow{3}{*}{5.994} & \multirow{3}{*}{0.003} & $\mathrm{C} 1^{\mathrm{b}}$ \\
\hline & & & & & & & $\mathrm{C} 2^{\mathrm{b}}$ \\
\hline & & & & & & & $\mathrm{C}^{\mathrm{a}}(p<0.01)$ \\
\hline
\end{tabular}

Widht

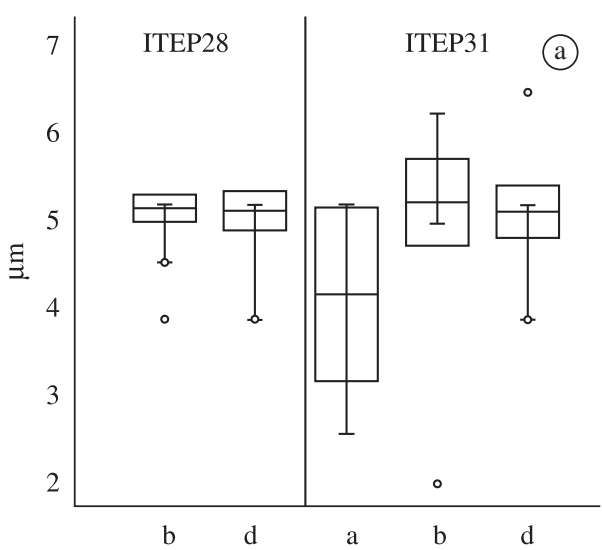

Lenght

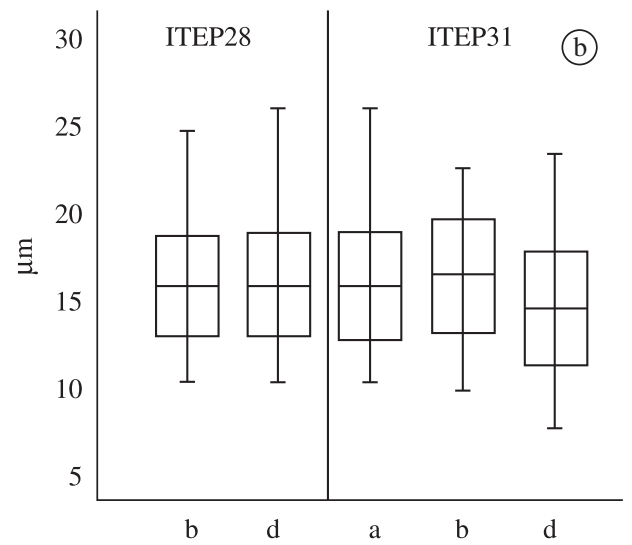

Figure 3. Dimensions of akinetes $(n=60-150)$ under different conditions for strains ITEP28 (straight) and ITEP31 (coiled); a. Width; b. Length; Assays: a) $30 \mu \mathrm{mol} \cdot \mathrm{m}^{-2} \cdot \mathrm{s}^{-1}$ and $21{ }^{\circ} \mathrm{C}$; b) $30 \mu \mathrm{mol} \cdot \mathrm{m}^{-2} \cdot \mathrm{s}^{-1}$ and $31{ }^{\circ} \mathrm{C}$; c) $90 \mu \mathrm{mol} \cdot \mathrm{m}^{-2} \cdot \mathrm{s}^{-1}$ and $21{ }^{\circ} \mathrm{C}$; d) $90 \mu \mathrm{mol} \cdot \mathrm{m}^{-2} \cdot \mathrm{s}^{-1}$ and $31^{\circ} \mathrm{C}$.

strains, respectively. The fastest growth rates occurred with the straight strain (ITEP28) $(\mathrm{V}(\mathrm{x})=3.21 ; 3.63 ; 3.89)$ and the slowest occurred with the coiled strain (ITEP31) $(\mathrm{V}(\mathrm{x})=0.97 ; 1.07 ; 1.61 ; 1.80)$ (Table 2; Figure 5). Maximal growth for both strains occurred around Day 100, with the exception of the coiled morphotype under the condition of $30 \mu \mathrm{mol} \cdot \mathrm{m}^{-2} \cdot \mathrm{s}^{-1} / 21{ }^{\circ} \mathrm{C}$.
The straight morphotype adapted to the conditions tested, demonstrating very similar metabolic times and high maximal growth rates, except when the light intensity was $90 \mu \mathrm{mol} . \mathrm{m}^{-2} \cdot \mathrm{s}^{-1}$ (Figure 6). The temperature of $21^{\circ} \mathrm{C}$ was not adequate for the development of this morphotype when combined with the higher light intensity $90 \mu \mathrm{mol} \cdot \mathrm{m}^{-2} \cdot \mathrm{s}^{-1}$. However, at the same temperature and in combination with 
Table 2. Estimates of the logistic model parameters, growth rate under different treatments and respective coefficients of determination $\left(\mathrm{R}^{2}\right) ; \phi_{1}$ : maximal population size after long period of time $(\mathrm{x} \rightarrow \infty) ; \phi_{2}$ : time required for population to reach half maximal size; $\phi_{3}$ : scale parameter, inversely proportional to maximal growth rate.

\begin{tabular}{|c|c|c|c|c|c|c|c|}
\hline Strain & $\begin{array}{c}\text { Temperature } \\
\left({ }^{\circ} \mathbf{C}\right)\end{array}$ & $\begin{array}{l}\text { Light intensity } \\
\left(\mu \mathrm{mol} . \mathrm{m}^{2} . \mathrm{s}^{-1}\right)\end{array}$ & $\begin{array}{c}\phi_{2} \\
\text { (days) }\end{array}$ & $\begin{array}{c}\phi_{1} \times 10^{6} \\
\text { (trichomes) }\end{array}$ & $\phi_{3}$ & $\begin{array}{l}\text { Max. growth rate } \\
\left(\text { trichome .day }{ }^{-1}\right)\end{array}$ & $\mathbf{R}^{2}$ \\
\hline \multirow{4}{*}{$\begin{array}{l}\text { ITEP28 } \\
\text { (straight) }\end{array}$} & \multirow{2}{*}{21} & 30 & 92.7 & 2.87 & 22.34 & $3.2110^{4}$ & 0.98 \\
\hline & & 90 & 1.20 & 0.75 & 60.21 & $0.3110^{4}$ & 0.97 \\
\hline & \multirow{2}{*}{31} & 30 & 98.4 & 2.63 & 18.12 & $3.6310^{4}$ & 0.99 \\
\hline & & 90 & 90.1 & 4.48 & 28.76 & $3.8910^{4}$ & 0.98 \\
\hline \multirow{4}{*}{$\begin{array}{l}\text { ITEP31 } \\
\text { (coiled) }\end{array}$} & \multirow{2}{*}{21} & 30 & 63.9 & 1.74 & 27.00 & $1.6110^{4}$ & 0.99 \\
\hline & & 90 & 163.5 & 2.40 & 61.63 & $0.9710^{4}$ & 0.96 \\
\hline & \multirow{2}{*}{31} & 30 & 99.0 & 1.04 & 24.34 & $1.0710^{4}$ & 0.96 \\
\hline & & 90 & 98.7 & 2.18 & 30.35 & $1.8010^{4}$ & 0.97 \\
\hline
\end{tabular}
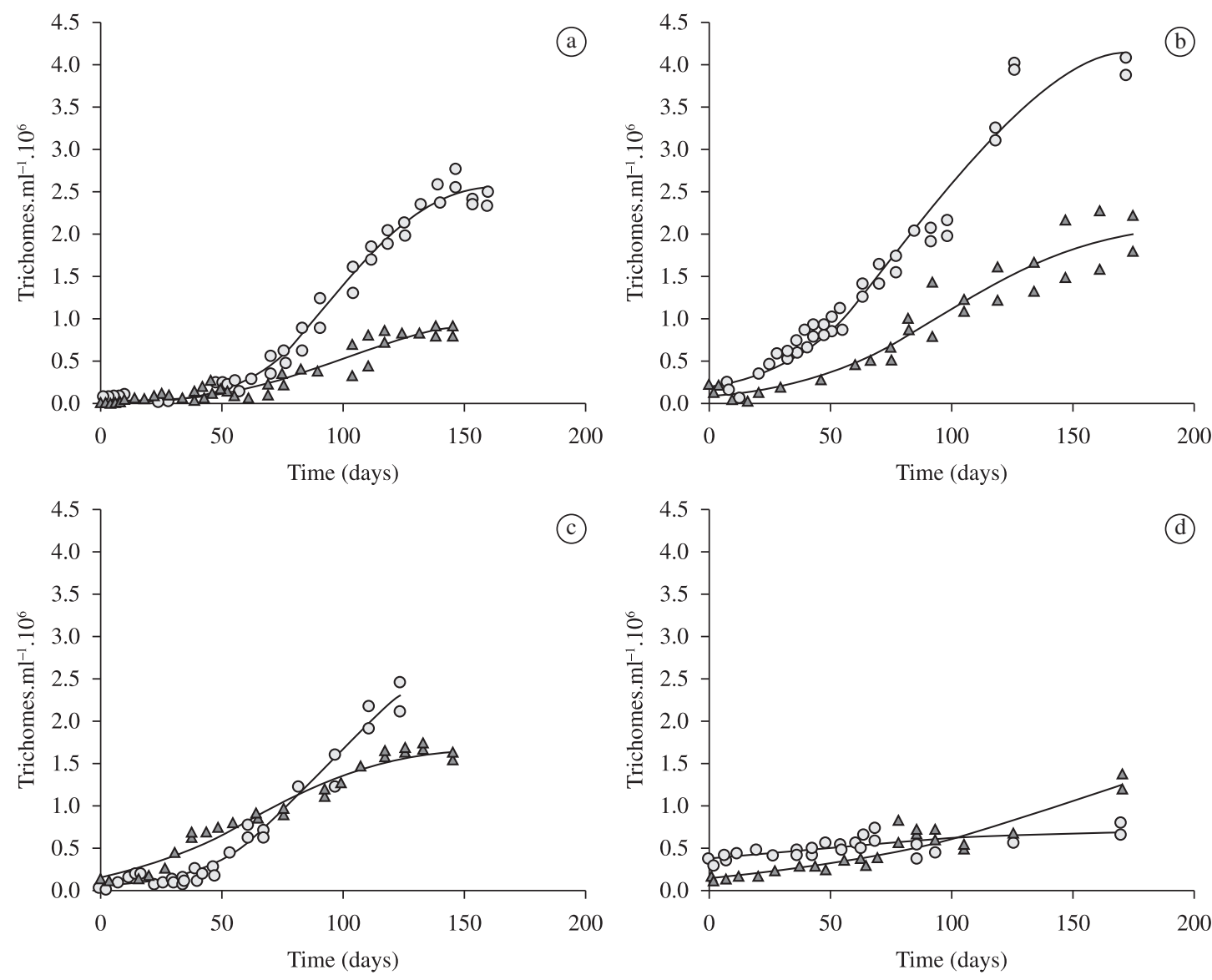

○ ITEP28 $\Delta$ ITEP31

Figure 4. Growth curves of strains ITEP28 (straight) and ITEP31 (coiled); Assays: a) $30 \mu \mathrm{mol}^{-2} \mathrm{~m}^{-2} \cdot \mathrm{s}^{-1}$ and $21{ }^{\circ} \mathrm{C}$; b) $30 \mu \mathrm{mol} \cdot \mathrm{m}^{-2} \cdot \mathrm{s}^{-1}$ and $31^{\circ} \mathrm{C}$; c) $90 \mu \mathrm{mol} \cdot \mathrm{m}^{-2} \cdot \mathrm{s}^{-1}$ and $21^{\circ} \mathrm{C}$; d) $90 \mu \mathrm{mol} \cdot \mathrm{m}^{-2} \cdot \mathrm{s}^{-1}$ and $31^{\circ} \mathrm{C}$.

the lower light intensity $\left(30 \mu \mathrm{mol} \cdot \mathrm{m}^{-2} \cdot \mathrm{s}^{-1}\right)$, the maximal growth rate was high $(\mathrm{V}(\mathrm{x})=3.21)$.

Although exhibiting slower growth rates than the straight morphotype, the coiled strain (ITEP31) developed well under all tested conditions. Regardless of the degree of luminosity, the coiled morphotype exhibited practically equal metabolic times at the temperature of $31^{\circ} \mathrm{C}$, with adequate growth rates for the development of the population. However, at the lower temperature $\left(21^{\circ} \mathrm{C}\right)$, light intensity had a decisive effect on metabolic time. 


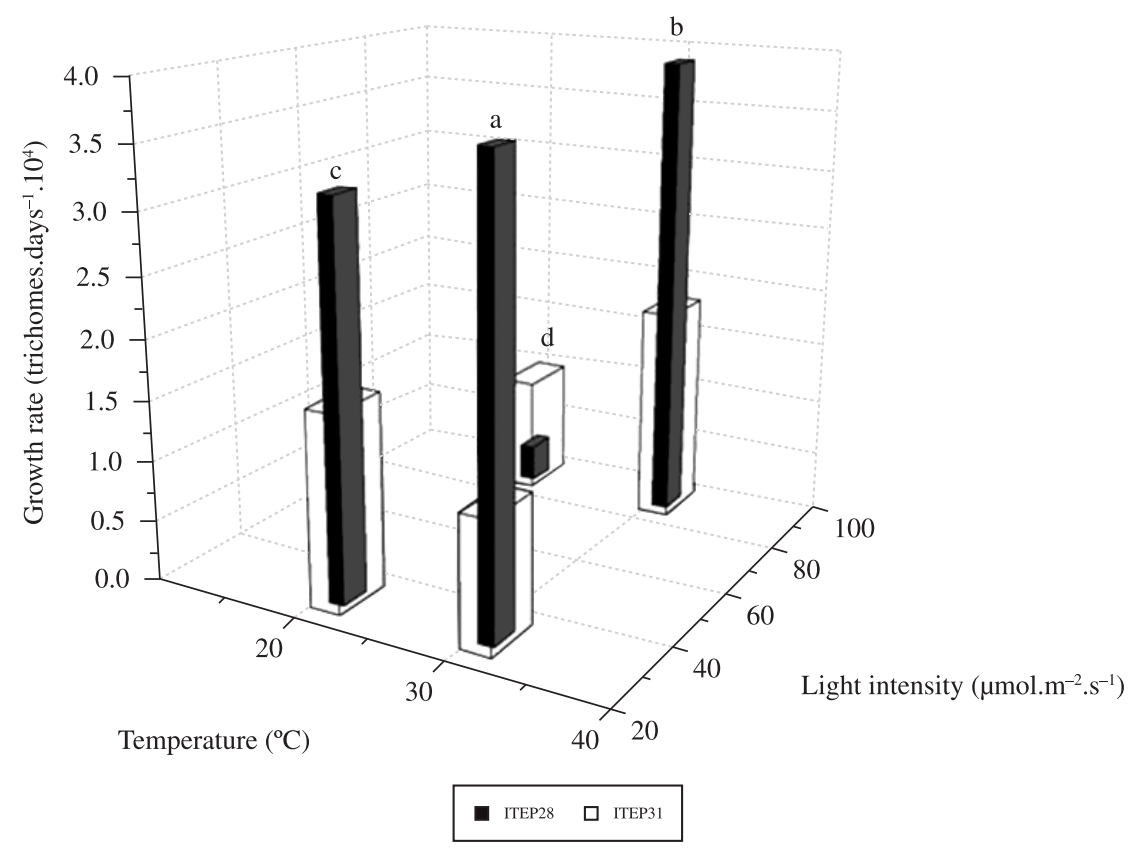

Figure 5. Comparison of maximal growth velocities of strains ITEP28 (straight) and ITEP31 (coiled); Assays: a) $30 \mu \mathrm{mol} \cdot \mathrm{m}^{-2} \cdot \mathrm{s}^{-1}$ and $31^{\circ} \mathrm{C}$; b) $90 \mu \mathrm{mol} \cdot \mathrm{m}^{-2} \cdot \mathrm{s}^{-1}$ and $31^{\circ} \mathrm{C}$; c) $30 \mu \mathrm{mol} \cdot \mathrm{m}^{-2} \cdot \mathrm{s}^{-1}$ and $21^{\circ} \mathrm{C}$; d) $90 \mu \mathrm{mol} \cdot \mathrm{m}^{-2} \cdot \mathrm{s}^{-1}$ and $21^{\circ} \mathrm{C}$.

\section{Discussion}

The molecular analysis indicated that both morphotypes belong to the same species, corroborating previous studies employing different molecular markers in C. raciborskii (Saker et al., 1999; Wilson et al., 2000; Dyble et al., 2002; Chonudonkul et al., 2004). The extreme phenotype plasticity of $C$. raciborskii is reported by a number of authors and is related to both biotic and abiotic factors (Bouvy et al., 1999; Komarková et al., 1999; Shafik et al., 2003). Saker et al. (1999) found that a temperature of $21^{\circ} \mathrm{C}$ hindered the population development of both straight and coiled morphotypes in Australia. Moreover, the authors report morphological alterations in the trichomes, such as constrictions in the cell wall, followed by fragmentation in individualised cells. Komárková et al. (1999) report that lower temperatures $\left(<20{ }^{\circ} \mathrm{C}\right)$ favour the emergence of anomalous forms in Brazilian strains of $C$. raciborskii.

In the present study, mean width values of the vegetative cells in both strains corresponded to those found in the original description of $C$. raciborskii (2.5 to $4.0 \mu \mathrm{m}$ ) (Woloszyńska 1912 apud Cronberg and Komárek, 2004) under all tested conditions (Figure 1).

The coiled strain exhibited greater phenotype plasticity than the straight strain in the morphology of the trichomes. Moreover, the straight morphotype did not become coiled at any time, and exhibited a tendency toward thinning and elongation of the trichomes in the stationary growth phase. Hawkins et al. (2001) report similar observations, with a progressive reduction in cell width during the stationary phase. The authors conclude that the reduction under light is due to self-shadowing caused by the increase in biomass leading to changes in the dimensions of the trichomes. This may be a strategy for the distribution of pigments in the cell in order to enhance their efficiency in capturing light. However, no reduction in cell width was found in the present study.

Production of akinetes only occurred under some conditions. This is a survival strategy when environmental conditions are unfavourable. This may explain the emergence of these cells soon after a growth decrease in both strains. Shafik et al. (2003) and Moore et al. (2004) suggest that high temperatures may be related to the differentiation of akinetes, which may explain the absence of akinetes at lower temperature $\left(21^{\circ} \mathrm{C}\right)$ in the present study.

The development of heterocysts occurred up to the end of the exponential phase in both strains under all tested conditions, except in the straight morphotype at the condition of $90 \mu \mathrm{mol} \cdot \mathrm{m}^{-2} \cdot \mathrm{s}^{-1} / 21^{\circ} \mathrm{C}$. Nitrogen fixation is a process known to require considerable energy expenditure and species from the order Nostocales require high degrees of luminosity in order to maintain it (MacCausland et al., 2005; Wiedner et al., 2007). According to Padisák (1997), the production of heterocysts occurs when there is a deficiency of nitrogen in the environment. In the present study, the culture medium was the same for all experiments. Therefore, the absence of heterocysts in the straight morphotype under the condition of $90 \mu \mathrm{mol} \cdot \mathrm{m}^{-2} \cdot \mathrm{s}^{-1} / 21{ }^{\circ} \mathrm{C}$ must not 

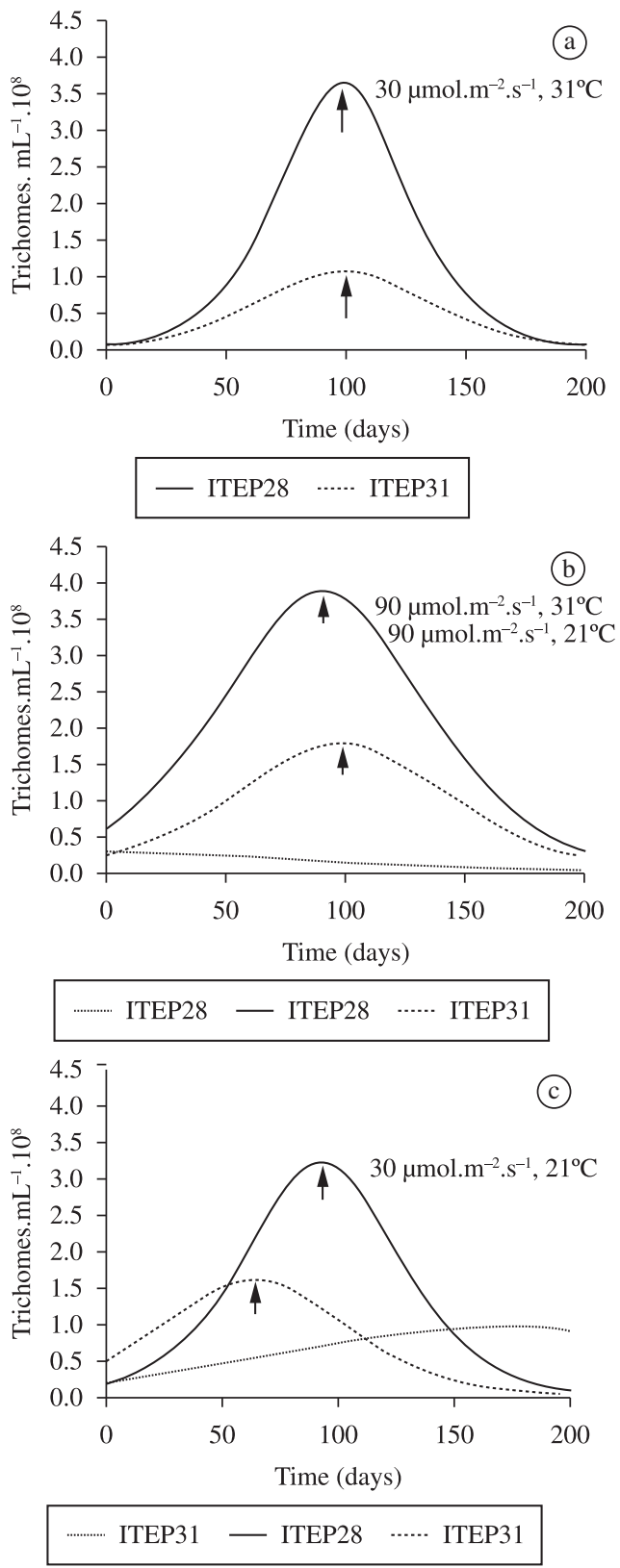

Figure 6. Growth rate curves of strains ITEP28 (straight) and ITEP31 (coiled); Assays: a) $30 \mu \mathrm{mol} \cdot \mathrm{m}^{-2} \cdot \mathrm{s}^{-1}$ and $31{ }^{\circ} \mathrm{C}$; b) $90 \mu \mathrm{mol} \cdot \mathrm{m}^{-2} \cdot \mathrm{s}^{-1}$ and $31{ }^{\circ} \mathrm{C}$; c) $30 \mu \mathrm{mol} \cdot \mathrm{m}^{-2} \cdot \mathrm{s}^{-1}$ and $21{ }^{\circ} \mathrm{C}$; dotted line represents $90 \mu \mathrm{mol} . \mathrm{m}^{-2} \cdot \mathrm{s}^{-1}$ and $21^{\circ} \mathrm{C}$ for comparison purposes; arrows indicate maximal growth velocity.

have been related to the concentration of nutrients, but rather to the combination of high light intensity and low temperature, which is unfavourable to the development of this morphotype.

In a study on populations of $C$. raciborskii in two lakes in Germany, Wiedner et al. (2007) found that growth initiated under light intensity ranging from
90 to $130 \mu \mathrm{mol}$.photons. $\mathrm{m}^{-2} \cdot \mathrm{s}^{-1}$ and at a temperature between 15 and $17{ }^{\circ} \mathrm{C}$. The authors concluded that light intensity is the most important factor in the regulation of population dynamics. Studying ten strains of $C$. raciborskii from both tropical and temperate regions submitted to different temperatures and light intensities, Briand et al. (2004) found no evidence of a supposed selection of organisms more adapted to these factors which would explain the invasion of the species at medium latitudes. The authors determined that various strains exhibited a wide range of physiological tolerance, which may facilitate their proliferation in temperate regions.

In the present study, both strains of $C$. raciborskii adapted to different temperatures and tested light intensities. However, neither morphotype tolerated luminosities above $130 \mu \mathrm{mol} . \mathrm{m}^{-2} . \mathrm{s}^{-1}$. Moreover, the coiled morphotype exhibited greater sensitivity to a higher light intensity, perhaps due to its spatial conformation, which allows receiving light from different angles.

\section{Conclusions}

- The morphotypes responded differently to the temperatures and light intensities tested;

- Both strains exhibited faster growth rates when submitted to higher light intensity and temperature. The condition of lower temperature and higher light intensity had a negative effect on the development of both morphotypes;

- Variations in cell morphometry and the absence of akinetes in both strains were related to the lower temperature condition $\left(21^{\circ} \mathrm{C}\right)$;

- The coiled morphotype exhibited considerable phenotype plasticity, changing the morphology of the trichome during the development of the culture;

- Although molecular analysis does not sustain the separation of the morphotypes as distinct species, their different ecophysiological responses should be considered to be of extreme importance for the population control of these potentially toxic organisms.

Acknowledgements - This study was supported by grants from CNPQ (Proc. 300794/2004-5, 500704/2004-0) and FAPESP (Proc. 2004/00939-6, 2007/57509-1) - Brazilian agencies for the promotion of Science.

\section{References}

AYRES, M., AYRES JÚNIOR, M., AYRES, DL. and SANTOS, AS., 2005. BioEstat: Aplicações estatísticas nas áreas das Ciências biomédicas. Belém: Sociedade Civil Mamirauá. 334 p.

BITTENCOURT-OLIVEIRA, MC., 2000. Development of Microcystis aeruginosa (Kützing) Kützing (Cyanophyceae/ Cyanobacteria) under cultivation and taxonomic implications. Algological Studies, vol. 99, p. 29-37.

BITTENCOURT-OLIVEIRA, MC., MOURA, AN., GOUVÊABARROS, S. and PINTO, E., 2007. HIP1 DNA fingerprinting 
in Microcystis panniformis (Chroococcales, Cyanobacteria). Phycologia, vol. 46, no.1, p. 3-9. http://dx.doi.org/10.2216/06-01.1

BITTENCOURT-OLIVEIRA, MC., MOURA, AN., HEREMAN, TC. and DANTAS, EW., 2011. Increase in straight and coiled Cylindrospermopsis raciborskii (Cyanobacteria) populations under conditions of thermal de-stratification in a shallow tropical reservoir. Journal of Water Resource and Protection, vol. 3, n. 4, p. 245-252. http://dx.doi.org/10.4236/jwarp.2011.34031

BOUVY, M., MOLICA, R., OLIVEIRA, S., MARINHO, M. and BEKER, B., 1999. Dynamics of a toxic cyanobacterial bloom (Cylindrospermopsis raciborskii) in a shallow reservoir in the semi-arid region of northeast Brazil. Aquatic Microbiology Ecology, vol. 20, p. 285-297. http://dx.doi.org/10.3354/ame020285

BRIAND, JF., LEBOULANGER, C., HUMBERT, JF., BERNARD, C. and DUFOUR, P., 2004. Cylindrospermopsis raciborskii (Cyanobacteria) invasion at mid-latitudes: selection, wide physiological tolerance, or global warming? Journal of Phycology, vol. 40, no. 2, p. 231-238. http://dx.doi.org/10.1111/j.1529-8817.2004.03118.x

CARIA, M., 2000. Measurement analysis: An Introduction to the Statistical Analysis of Laboratory Data in Physics, Chemistry and the Life Sciences. London: Imperial College Press. 229 p.

CHONUDONKUL, D., YONGMANITCHAI, W., GUNJANA, T., KAWACHI, M., KASAI, F., KAYA, K. and WATANABE, MM., 2004. Morphology, genetic diversity, temperature tolerance and toxicity of Cylindrospermopsis raciborskii (Nostocales, Cyanobacteria) strains from Thailand and Japan. FEMS Microbiology Ecology, vol. 48, no. 3, p. 345-355. PMid:19712304. http://dx.doi. org/10.1016/j.femsec.2004.02.014

CRONBERG, G. and KOMÁREK, J., 2004. Some Nostocalean Cyanoprocaryotes from lentic habitats of Eastern and Southern Africa. Nova Hedwigia, vol. 78, no. 1-2, p. 71-106. http://dx.doi. org/10.1127/0029-5035/2004/0078-0071

DYBLE, J., PEARL, HW. and NEILAN, BA., 2002. Genetic characterization of Cylindrospermopsis raciborskii (Cyanobacteria) isolates from geographic origins based on nifH and $c p c$ BA-IGS nucleotide sequence analysis. Applied Environmental Microbiology, vol. 68, no. 5, p. 2567-2571. PMid:11976136. PMCid:127569. http://dx.doi.org/10.1128/AEM.68.5.2567-2571.2002

FABBRO, LD. and DUIVENVOORDEN, LJ., 1996. Profile of a bloom of the cyanobacterium Cylindrospermopsis raciborskii (Woloszynska) Seenaya and Subba Raju in Fitzroy river in tropical central Queensland. Marine and Freshwater Research, vol. 47 , p. 685-694

GUILLARD, RRL., 1973. Division rates. In Stein, JR. Handbook of phycological methods: culture methods and growth measurements. Cambridge: Cambridge University Press. p. 289-311.

HAWKINS, PR., PUTT, E., FALCONER, I. and HUMPAGE, A., 2001. Phenotypical variation in a toxic strain of the phytoplankter, Cylindrospermopsis raciborskii (Nostocales, Cyanophyceae) during batch culture. Environmental Toxicology, vol. 16, no. 6, p. 460-467. PMid:11769242. http://dx.doi.org/10.1002/tox.10005

JACCARD, P., 1901. Étude comparative de la distribution florale dans une portion des Alpes et des Jura. Bulletin de la Société Vaudoise des Sciences Naturelles, vol. 37, p. 547-579.

KOMÁRKOVÁ, J., LAUDARES-SILVA, R. and SENNA, PAC., 1999. Extreme morphology of Cylindrospermopsis raciborskii (Nostocales, Cyanobacteria) in the Lagoa do Peri, a freshwater coastal lagoon, Santa Catarina, Brazil. Algological Studies, vol. 94 , p. 207-222.

Mac CAUSLAND, MA., THOMPSON, PA. and BLACKBURN, SI., 2005. Ecophysiological influence of light and mixing on Anabaena circinalis (Nostocales, Cyanobacteria). European Journal of Phycology, vol. 40, no. 1, p. 9-20. http://dx.doi. org/10.1080/09670260400019758

MOORE, D., McGREGOR, GB. and SHAW, G., 2004. Morphological changes during akinetes germination in Cylindrospermopsis raciborskii (Nostocales, Cyanobacteria). Journal of Phycology, vol. 40, no. 6, p. 1098-1105. http://dx.doi. org/10.1111/j.1529-8817.2004.04050.x

PADISÁK, J., 1997. Cylindrospermopsis raciborskii (Woloszynska) Seenayya et Subba Raju, an expanding, highly adaptative cyanobacterium: worldwide distribution and review of its ecology. Archives für Hydrobiology, vol. 107, p. 563-593.

RIPPKA, R., DERUELLES, J., WATERBURY, JB., HERDMAN, M. and STANIER, RY., 1979. Generic assignments, strain histories and properties of pure cultures of cyanobacteria. Journal of General Microbiology, vol. 111, p. 1-61.

SAKER, ML., NEILAN, BA. and GRIFFITHS, DJ., 1999. Two morphological forms of Cylindrospermopsis raciborskii (Cyanobacteria) isolated from Solomon Dam, Palm Island, Queensland. Journal of Phycology, vol. 35, no. 3, p. 599-606. http://dx.doi.org/10.1046/j.1529-8817.1999.3530599.x

SHAFIK, HM., VÖRÖS, L., SPRÓBER, P., PRÉSING, M. and KOVÁCS, A., 2003. Some special morphological features of Cylindrospermopsis raciborskii in batch and continuous cultures. Hydrobiologia, vol. 506-509, no. 1-3, p. 163-167. http://dx.doi. org/10.1023/B:HYDR.0000008588.89048.70

WIEDNER, C., RÜCKER, J., BRÜGGEMANN, R. and NIXDORF, B., 2007. Climate change affects timing and size of populations of an invasive cyanobacterium in temperate regions. Oecologia, vol. 152, no. 3, p. 473-484. PMid:17375336. http://dx.doi.org/10.1007/ s00442-007-0683-5

WILSON, KM., SCHEMBRI, MA., BAKER, PD. and SAINT, CS., 2000. Molecular characterization of toxic cyanobacterium Cylindrospermopsis raciborskii and design of a species-specific PCR. Applied Environmental Microbiology, vol. 66, no. 1, p. 332-338. PMid:10618244. PMCid:91826. http://dx.doi. org/10.1128/AEM.66.1.332-338.2000 
